DOI: $10.1515 /$ rpp-2017-0045

Doctor of Pedagogical Sciences, Full Professor, TYMOFII DESIATOV

The Bohdan Khmelnytskyi National University of Cherkasy, Ukraine Address: 81 Shevchenko Blvd, Cherkasy, 18031, Ukraine

E-mail: desyatov50@ukr.net

\title{
COMPARATIVE PEDAGOGICAL STUDIES ON MODELS OF EDUCATION SYSTEMS MANAGEMENT IN THE EU AND UKRAINE
}

\begin{abstract}
The article highlights the peculiarities of models of education systems management in the EU and Ukraine. It has been proved that effectiveness of the education process is determined by managerial culture, which characterizes a manager's professional image. Special attention has been paid to finding the right balance between centralization and decentralization, national goals and regional or local interests. It has been emphasized that this balance should take into account the features of each country, region. It has been found out that centralized education management systems in some countries and decentralized ones in others are preserved due to specifics of the national traditions. It has been revealed that these two models of management have tendencies for convergence. The relationship between the model of education management and a teacher's pedagogical style has been investigated. It has been emphasized that a managerial component should be transformed into professional and personal qualities. It has been stated that education managers' quality is considered to be a priority for the countries-participants of the Bologna process, including Ukraine, as it is taken into account as a leading condition for establishing trust, correlation, mobility, comparability and attractiveness. It has been noted that education managers' training is associated with a complex of direct and remote psychological and pedagogical problems arising under the influence of scientific and technological transformations: a person's employment, their intellectual development, biophysical state. It has been revealed that the management model development does not correspond to the level of the management object development in all EU countries. In this context, the fact should be taken into account that in the EU countries there are processes of transformation of national thinking in continental one, which somehow diminishes the traditional cult of the nation.

Keywords: management models, centralization, decentralization, management component, ambivalent, New Ukrainian school, integration, pedagogical management.

\section{INTRODUCTION}

The growing demands of the labour market, rapid technological changes, globalization, the growth of academic and labour mobility actualizes the need for studying models of education systems management in the EU countries, the relationship between a managerial component and education managers' training quality.

Under the conditions of education's increasing role in society and intensification of economic and cultural integration processes, the study on models of education systems management in the EU and in Ukraine has proved to be logical, since geographical and socioeconomic transformations have increased mobility of European and Ukrainian citizens. Therefore, it is important to conduct comparative analysis on education managers' training in these countries.
\end{abstract}


THE AIM OF THE STUDY

The aim of the study is to conduct comparative pedagogical analysis on models of education systems management in the EU in the context of philosophical, psychological, pedagogical and legislative aspects, to study the dynamics of development of education systems management models based on research findings by Ukrainian and foreign scholars.

\section{THEORETICAL FRAMEWORK AND RESEARCH METHODS}

The study of information sources have become possible due to significant amount of theoretical material, recognized theoretical conceptions and other studies. The basis of the study includes current research findings on the abovementioned issues.

To obtain the facts needed, Ukrainian and foreign documentation were studied, Internet sources were used and scientific articles were analyzed. Theoretical aspects of the study on models of education systems management as a scientific phenomenon have been presented in the works by many researchers in Ukraine (N. Avshenyuk, N. Bidyuk, V. Kremen, N. Nychkalo, A. Sbruieva, B. Vulfson et al.). Foreign scholars' research findings prove topicality and multidimensionality of the problem of education systems management (K. Anderk, A. Harris, J. Raven, L. Weber). These issues are crucial ones in legal documents on the national education system development, namely, the National Doctrine of Education Development in Ukraine, the Law of Ukraine "On Education", voted by the Verkhovna Rada on September $5^{\text {th }}, 2017$.

While researching we have used such methods as analysis, synthesis, analogy, comparison, individualization and generalization.

\section{RESULTS}

Comparative analysis of education managers' training indicates that Western education system has obtained great experience in this regard. The Council for Cultural Cooperation at the Council of Europe, under the auspices of which the European Forum on Educational Administration was established in 1996, attaches great importance to its study. Having studied the materials of the Forum's seminars we concluded that in most EU countries the system of education managers' training, in particular school leaders' training, consists of three links, namely, the basic link at the level of higher pedagogical education; the study on specifics of early work experience; improvement of professional skills during professional activities. The mechanism of teaching is its management, but not the transfer of educational information by the subject of the education process.

It should be noted that a complex set of immediate and remote psychological and pedagogical problems arising under the influence of scientific and technological transformations such as a person's employment, their intellectual development, biophysical status is connected with education managers' training.

Education managers' training quality is considered to be a priority for the countriesparticipants of the Bologna process, including Ukraine, as it is taken into account as a leading condition for establishing trust, correlation, mobility, comparability and attractiveness (European Parliament, 2000; European Comission, 2004; Obzor evropeiskogo, 2010).

However, effectiveness of the education process, including learning activities, mainly depends on how competently a managerial component of educational work is implemented by a manager. However, it is necessary to take into account that it is possible to manage systems and processes; lead individuals and teams. It is assumed that one can manage something and lead someone. It is well-known that effectiveness of the education process is determined by managerial culture, awareness of managerial functions, since managerial culture characterizes a manager's professional image. It should be understood that in all EU 
countries development of a management system does not correspond to the level of development of the object of management. In this context, the fact should be taken into account that in the EU countries there are processes of transformation of national thinking in continental one, which somehow diminishes the traditional cult of the nation.

In the countries-members of the Council of Europe, international strategies provide for a number of measures and management mechanisms for its implementation. The success of these strategies depends to a large extent on the expectations society puts on the sector of life that is important to it, that is, education. That is why the education policy in Europe is primarily aimed at taking into account the interests of society (Ovcharuk, 2013).

The European Forum of Educational Administration examines the current state of education managers' training system in terms of such aspects as a type of the system of training and retraining of educational institutions leaders (centralized/ decentralized); training duration; main goals and content of training; forms and methods of the education process organization (lectures, practical classes, individual study, workshops, observation and training on managerial decision making, etc.); tuition fees, etc.

Within our study we would like to characterize the process of appointing a school leader in France. It is based on a competition only for French citizens, who should not be less than 30 years old and should have five-year teaching experience. Four-hour written exams allow the candidates to demonstrate their ability to analyze the situation in a real school, justifying their administrative and pedagogical decision. An oral exam includes a personal interview with a candidate, who must introduce themselves and explain their motivation. Usually, the competition implies 3-4 candidates for one position. Having passed the exam, the candidates study for six months in schools of different types and undergo four-six week placements. Next they are appointed school leader assistants for two years. During this time it is necessary to undergo special training in an individual programme (21 days). A regional education authority sanctions an appointment to the position of a school director.

Quite topical in the EU countries is the search for the balance between centralization and decentralization, national goals and regional or local interests. This balance must take into account the peculiarities of each country and region.

In the context of decentralization in accordance with the UNESCO recommendations, the state should perform the following functions, namely, to develop the education policy concepts, to define strategic goals and objectives of education development, to support general socioeconomic balance in the education system functioning. Regions should define and coordinate development strategies for educational institutions and disseminate their regional economic relations. Local governments are called to ensure closer and more effective cooperation between educational institutions in one region. In their turn, local self-government bodies should maintain contact with public associations, thus providing direct contact with consumers of educational services.

The decentralization trend in the EU countries does not contradict the fact that the state, represented by its central body, has primary responsibility for the state of education and plays a decisive role in its development; it is the guarantor of its normal and organic functioning.

The experience of developed European countries suggests that centralization does not necessarily involve authoritarianism, and decentralization does not always lead to democracy.

S. Lurie notes, "It seems that it is not always possible to establish a correlation between a high degree of decentralization and democratization of society...". 
It has been found out that centralized education management systems in some countries and decentralized in others are preserved due to the specifics of national traditions. However, taking into account globalization processes, these two models of management have tended to converge. L. Weber indicates that in the course of French education system modernization and development, it is important to take into account such factors as decentralization, the European Union's influence on education policy, marketing and commercialization of education as global trends (Veber, 2003). So, the search for an optimal management model is in line with the current need for education development in the third millennium.

The study and comparative analysis on European experience in training and retraining education managers is particularly relevant due to transformation of the system of higher pedagogical education in Ukraine. The problem of education management has been one of the most difficult due to the need for creating such schemes that would enable to identify the main parameters of fundamentally different management models centralized and decentralized. Scholars state that the starting point for identifying the basic parameters of education systems in different countries should be a degree of administrative centralization in the system of education management.

The centralized system has administrative structures that represent the central government and are responsible for implementation of the national education policy. With the help of such a system, local authorities monitor implementation of the center's instructions. A local initiative or local "participation" begins right after the education policy has been developed and ready for implementation by those means and methods, which are chosen by higher authorities.

Simultaneously, the traditional approach continues operating in Ukraine to address the objectives set by the central education authority, while the initiative to transform these objectives into regional and local conditions and needs is rather low. Regional education policy under the conditions of decentralization in all spheres of society's life should combine the state education policy and the regional education policy.

Decentralized models provide different opportunities for development of initiatives and innovations in the education system. These initiatives can be offered by central education authorities, independent educational institutions at all levels, or be the subject of independent agreements between stakeholders. Changes in the conditions of such an education system are introduced not simultaneously in all educational institutions, but gradually, guided by the initiative from below.

It is not relevant to consider which model of education management in Western Europe is better, since historically the continent has a wide range of approaches and traditions in this direction. According to the data provided by the Council of Europe, there are three types of education management systems within the continent: 1) centralized (Albania, Belarus, Bulgaria, Estonia, Ireland, Italy, Latvia, Lithuania, Moldova, the Netherlands, Portugal, Romania, Slovenia, Turkey, Ukraine, Croatia); 2) education systems that are on the path to decentralization (Austria, Spain, Poland, France, the Czech Republic; 3) decentralized (Belgium, Great Britain, Germany, Greece, Denmark, Luxembourg, Norway, Switzerland, Sweden).

It must be noted that this is only an approximate (even somewhat doubtful) classification, since not all education systems can be characterized so unambiguously and categorically. In addition, in many countries there are significant changes in domestic and foreign policy that affect the organization of the education system in particular. 
The materials of the Council of Europe show that at the pan-European level, the development of all three systems of education management has begun to be explored and projected. However, at the present stage, centralized and decentralized education systems have much more attracted the attention of politicians, the public and academics. According to the documents, in centralized systems, much of the administrative and financial power is concentrated in the hands of the state: the distribution of resources; opening and closing of schools and other educational institutions; forming and approval of curricula; examination organization; financial control (Vulfson, 1997).

By exploring modern processes in centralized education systems, Western experts outline the trend in mitigating and diversifying control by the center through the transfer of some administrative and managerial powers to regional and local authorities (municipal authorities, inspectors, school departments, school administration, governing bodies of certain universities, subdivisions within the university).

Such a policy of transferring administrative functions to regional and local authorities is actively conducted in Bulgaria, Romania and the Czech Republic. The transfer of legislative powers of regional and local authorities leads to more efficient use of reserves, increasing susceptibility of educational structures to students' needs. The experience of foreign countries proves that successful implementation of such a policy requires an increase in local resources: personnel, infrastructure and financing. Otherwise, decentralization will be identified with the transfer of "powers" to the middle and bottom sectors, provided that management centralization is preserved. In addition, there is a threat of self-rule of the regional elites and local administration. However, the transfer of authority from one official to ten others is not decentralization yet.

When formulating new approaches to managing the education system in Ukraine, it is important to consider the fact that this system is responsible for ensuring equal opportunities for education. As a result of the transition from the state system to various forms of non-state education, a network of paid educational institutions has been created, which, indeed, were intended only for privileged social circles. Among such establishments a special place is occupied by schools of a new type, which attract theorists, practitioners and the pedagogical community's attention. As a result, the emigration of qualified personnel from the mass school, state higher education institutions is observed. The outlined problem being educational has become sociopolitical. For instance, male teachers tend to leave schools, which results in an increase of their feminization: $83 \%$ of teaching staff working in the Ukrainian education system are women. The teacher is greatly dissatisfied with the low social status of their profession and school, that is, indeed, the most important state institute of social reproduction, and is forced to look for another job. The reason is that teaching is not appreciated adequately to the role that the teacher plays in society. Besides, there are certain contradictions in the state of the teacher's professional activity: between the increase in the volume of scientific and specialized information and traditional pedagogical technology, between the growing requirements for teachers' professional skills and the lack of qualifications, between the increasing objective social significance of teaching profession and actual underestimation of their activities by society. B. Vulfson considers this problem to be the problem of an "effective teacher".

Due to the low social status of the teacher, this profession is not chosen by the most talented youth. Teaching profession is not admired by gifted boys and girls. They can earn more, have better working conditions, feel respected by society, work in public administration or business. In addition, teachers work with physically and socially 
immature individuals, that requires them to have special skills, good qualities and make volitional efforts. Therefore, it is not surprising that, according to the researches by Ukrainian and foreign scientists, a quarter, a third, and in some cases, $40 \%$ of graduates of pedagogical education institutions are not motivated toward their profession. As a result, among the teachers become aware of the domination of informational approach and reproductive forms in education, a weak initiative of the students in choosing ways of professionalism due to the lack of external conditions that allow determining the individual line (strategy) for acquiring relevant education. It is obvious that the general content of teacher's training should be determined by the goals and objectives of the education process in the general education school as a whole, and special knowledge is also defined as the subject that the future teacher will teach. The leaders of educational institutions should remember that templatization of the management process, the lack of motivation, the focus on personality development can prevent effectiveness of the process of organizing algorithmic activities and will not provide the expected result. In this context, V. Kremin notes "the current state of Ukrainian education is characterized as ambivalent, that is, there is awareness of the need for reforming, but development of innovations is hampered by financial difficulties" (Kremin, 2000).

Modern society needs projective pedagogy, namely, a system of intellectual and psychological development, which forms the person's creative thinking. Effectiveness of teacher's work should be evaluated by analyzing students' activities at classes, rather than the teacher's activities. Pedagogical university students should become active subjects of the education process. Teachers should focus on the interaction of theoretical and practical aspects of educational subjects, development of students' practical skills in the process of all forms of training and a number of pedagogical practices.

Scholars have proved that motivation as the engine of human development occupies a leading place in the structure of personality and activities.

It has been found out that the reforms of school and pedagogical education in the late 1980-90s in Europe contributed to convergence of the national education management systems. In the context of forming the pan-European educational space, these two fundamentally different management strategies tend to converge. In countries with a decentralized model of education management, the influence of central government in all components of education, in particular, content, is intensified. In countries with a centralized and semi-centralized management system, the process of introducing regional administrations into the system of teachers' training, retraining and certification has begun.

Theoretically, the pedagogical concept of education effectiveness serves as the basis for improving management of pedagogical education. Scholars state that all sectors of the management system are covered by the reforming process, various models of the most effective planning are being tested, interstate integration in the field of education is under way and measures are being implemented to coordinate pedagogical research in separate countries. Among the top scientific issues in Europe is the study on the teacher's role in the process of education democratization. Researchers indicate, in particular, the relationship between the model of education management and the style of the teacher's teaching activities. The materials presented by the Council of Europe have repeatedly emphasized that this problem is currently of particular relevance to the countries of Central and Eastern Europe, where a new understanding of the teacher's role in the education system as a whole emerges in the process of restructuring social and educational systems (Sbruieva, 2004).

In the context of the new Law of Ukraine "On Education", approved by the Verkhovna Rada of Ukraine on September $5^{\text {th }}$, 2017, it must be noted that the function of 
realizing the state education policy and ensuring its quality, collecting and publishing statistics, ensuring accessibility of institutions, equal conditions for development of institutions of all forms of ownership, etc. remains the responsibility of local self-governments. This means that regional councils and councils of territorial communities can independently solve the problem of their own structure. The Law also provides more freedom in solving staffing issues, more responsibilities with the organization of the education process, including consideration of school syllabi and curricula.

However, candidates will be able to be appointed to the position of a school leader only through the competition and will be allowed to reserve the position only for 12 years. In addition, the powers of educational institutions leaders will be balanced by public selfgovernments in educational institutions and supervisory boards (trustees).

"The main idea of the Law is a competitive, modern patriot, innovator, developed personality that will create a modern European Ukraine."

The Law also clarifies linguistic aspects, defines the minimum salary at the level of four subsistence minimums, abolishes competitive selection of children to the first form (Zakon Ukrainy, 2017).

The new Law "On Education" should launch a fully implemented reform of secondary education, the New Ukrainian School. It provides fair access to quality education, system change and decentralization of education management, reorientation towards forming key competencies. This will cause updating education standards, gradual transition to a three-year high school and ensuring profilization.

The Law is based on the standards that will help to provide more children with pre-school education and develop professional education.

The reforming of school education system in Ukraine presupposes not only adoption of a new law and introduction of the concept. First of all, it concerns teachers' psychological readiness to work in a new normative field under the conditions of new public expectations.

The teacher is given more freedom, but more responsibility and independence are expected. The new Ukrainian school comes from the fact that there is a child, not a method in the center of the education process. Relationships are built on a partnership between the teacher, the student, parents, as well as cooperation between the teachers themselves.

It requires not only "upgrade" of qualifications, but also "refreshing" teacher's personality. Thus, the teacher needs new conditions to develop. After all, the teacher cannot teach our children to be free, when they themselves do not have freedom - professional, financial, emotional - for their own development and growth (Skyba, 2017).

The new Law, unlike the previous one, guarantees academic freedom, encourages a pedagogical initiative - including development of author's curricula, projects, educational methods and technologies. The current Law also contains a reference to individual pedagogical activities, but this is also limited.

It should be noted that introduction of the ideas of the New Ukrainian School will in fact demand additional training, initiative and fresh approaches from teachers, but also increases the range of opportunities for these efforts to be well rewarded.

It is clear that these changes in school are inevitable, because they are dictated by the attitude of the modern generation and life itself.

Among the issues related to implementation of the outlined programme and the Law, a special place is connected with the problems of professional training of educational institutions leaders and quality of pedagogical work in accordance with the needs of 
society: first and foremost, development of the pedagogical education concept and reforming training of teaching staff; development of pedagogical education standards and the system of evaluation of pedagogical workers' professional competency; creation of a new generation of software and educational and methodological support of the education process in accordance with state standards. It is known that the European system of education quality assurance is based on European standards and recommendations. Foreign experience shows that scientific provision of education managers' training is carried out simultaneously by research teams of many countries, whose priority areas are design of future processes for development of pedagogical education and creation of alternative concepts for managers' training.

Scientific analysis of the state of affairs and own practical experience show that management of many leaders of educational institutions of all types and levels in Ukraine is implemented at the reproductive level, when the main thing is that the content and direction of management actions correspond to generally recognized and officially approved techniques and means of organizational work in educational institutions. At this level of activity goals that would motivate the search for independent solutions for improving the management system practically do not advocate in the process of implementing management activity.

Ukrainian educators need to create a mechanism for "tranlating the work requirements into the language of education", focusing on learning outcomes rather than learning.

This means the need to integrate Ukrainian education into the world educational system while preserving development of the Ukrainian school traditions; continuity of the process of obtaining education; education management decentralization; education variability, which creates conditions for free choosing the forms and methods of teaching, syllabi, programmes, specialization.

Based on this, effectiveness of a managerial component for implementing certain objectives should be determined: the number of teachers working according to a new technology; availability of teaching aids; international cooperation; the number of foreign international projects for educational institutions to participate; the number of students sent abroad for studies and internship; the number of students participating in international student competitions, contests and their results.

That is, a managerial component must be transformed into professional and personal qualities.

Modern management is a specific type of management activities, and pedagogical management is a theory of management in an educational institution, a system for managing the activities of an educational institution.

\section{CONCLUSIONS}

Consequently, the study on the works by Ukrainian and foreign researchers, as well as their own experience, shows that, firstly, effectiveness of the education process, in particular, educational activities, mainly depends on how competently a managerial component of educational work is implemented by a manager. Secondly, effectiveness of the educational process is determined by managerial culture, awareness of managerial functions, since managerial culture characterizes a manager's professional image. Thirdly, the process of a manager's professional development may be mandatory or conditional. Besides, professional development has a significant impact on a manager's behaviour. It should be added that effectiveness of professional development of educational institutions leaders is multicomponent and involves leadership, knowledge and available resources, a high level of cooperation, an appropriate evaluation of work and support. 


\section{REFERENCES}

1. European Parliament. (2000). Lisbon European Council 23 and 24 March 2000. Presidency conclusions. Retrieved from http://www.europarl.europa.eu/summits/lis1 en.htm.

2. European Commission. (2004). Common European principles for teacher competences and qualifications. Brussels: European Commission.

3. Kremen, V. H. (2000). Systema osvity v Ukraini: suchasni tendentsii i perspektyva. Profesiina osvita: pedahohika, 2, 11-30.

4. Obzor evropeiskogo opyta internatcionalizatcii obrazovaniia: naukove vidannia. (2010). Kharkov: NUA, 2010.

5. Ovcharuk, O. V. (2013). Mizhnarodni stratehii zaprovadzhennia osvity dlia demokratychnoho hromadianstva u krainakh rady Yevropy. Porivnialna profesiina pedahohika, 1 (3), 136-143.

6. Sbruieva, A. A. (2004). Tendentsii reformuvannia serednoi osvity rozvynenykh anhlomovnykh krain v kontekst hlobalizatsii (90-ti rr. XX - pochatok XXI st.). Sumy: VAT "Sumska oblasna drukarnia"; Kozatskyi val".

7. Skyba, M. (2017, Lypen 11). Novyi zakon pro osvitu. Komu vin vyhidnyi. Ukrainska pravda. Vziato z https://ife.pravda.com.ua/society/2017/06/29/224978/.

8. Veber, L. (2003). Problemy obrazovatelnoi sistemy vo Frantcii. Vziato s http://www/rambler.Roditel.ru/

9. Vulfson, B. L. (1997). Upravlenie na zapade: tendencii centralizacii i decentralizacii. Pedagogika, 2, 110-117.

10. Zakon Ukrainy "Pro osvitu": chynne zakonodavstvo stanom na 28 veresnia 2017 roku. (2017). Kyiv: Palyvoda A. V. 